\title{
First record of Pythiopsis cymosa de Bary (Saprolegniales: Oomycota) from freshwater fish in Brazil
}

\author{
J. R. S. Rocha ${ }^{a, b *}$ and B. M. Soares \\ aPrograma Regional de Pós-graduação em Desenvolvimento e Meio Ambiente - PRODEMA, Mestrado em \\ Desenvolvimento e Meio Ambiente - MDMA, Núcleo de Pesquisa no Trópico Ecotonal do Nordeste - TROPEN, \\ Universidade Federal do Piauí - UFPI, Campus Ministro Petrônio Portella, Avenida Universitária, 1310, Bairro Ininga, \\ CEP 64049-550, Teresina, PI, Brazil \\ bDepartamento de Biologia, Centro de Ciências da Natureza, Universidade Federal do Piauí - UFPI, Campus Ministro \\ Petrônio Portella, Avenida Universitária, s/n, Bairro Ininga, CEP 64049-550, Teresina, PI, Brazil \\ 'Laboratório de Citogenética Humana, Instituto de Ciências Biológicas, Universidade Federal do Pará - UFPA, Campus \\ Guamá, Rua Augusto Corrêa, 1, CEP 66075-110, Belém, PA, Brazil \\ *e-mail: ribamar10@hotmail.com
}

Received: July 20, 2016 - Accepted: October 21, 2016 - Distributed: May 31, 2018

(With 1 figure)

Once observed that oomycetes could cause diseases in fish, the term "saprolegniosis" was employed for these diseases, thus Saprolegniosis reports do not necessarily include only organisms belonging to the order Saprolegniales. Organisms of other orders may also cause diseases in fishes and other aquatic animals. These organisms can generally live as saprophytes, colonizing various types of substrates such as animal or vegetable remains (Johnson et al., 2002). This parasitism affects the fish and is known as "fish mold" and "fish mildew." The parasite hyphae grow in clumps on the fish skin which is why the term "cotton wool" is given to this disease.

Study with these organisms conducted in ornamental fish farm in Teresina, Piauí, showed the occurrence of Pythopsis cymosa de Bary isolated from skin lesions of the ornamental Silver Hatchetfish (Gasteropelecus sternicla Linnaeus, 1758), forming proliferation of hyphae in lesions with the characteristic appearance of "cotton wool".

Currently, four species are recognized as belonging to the Pythiopsis (Johnson et al., 2002). The species of Pythiopsis occurring in Brazil are $P$. humphreyana Coker in the state of Amazonas and Minas Gerais; P. irregularis R. L. Seym. in the state of Amazonas; and P. papilliformis R. L. Seym. in the state of Amazonas (Johnson et al., 2002; Milanez et al., 2007). On analyzing and reviewing the relevant literature, no report was found on the occurrence of $P$. cymosa in Brazil (Milanez et al., 2007; Steciow et al., 2012; Maia and Carvalho, 2015).

The studies were conducted in ornamental fish farm in Teresina, state of Piauí, Brazil, from May to August 2006, $\left(50^{\circ} 65^{\prime} 3.92\right.$ " S, $42^{\circ} 83$ '36.76" W). Dead fish with disease symptoms were collected from farm, packed in plastic bags, placed in coolers and taken to the laboratory of Zoosporic Organisms of the Federal University of Piauí. Initially, the skin lesions of infected fish were scraped with the aid of a sterilized scalpel. Slides were prepared with the collected material and examined under a microscope for an initial analysis of the pathogen. The oomycete observed was identified as P. cymosa using Johnson et al. (2005) key to species. After taxonomic identification, cultures were deposited in the collection of cultures of the Laboratory of Zoosporic Organism of the Federal University of Piauí, access ZFBR 110.

P. cymosa isolates showed mycelium moderately branched, with hyphae slender. Zoosporangia globose, clavate, cylindrical, sometimes lobed or branched; renewed cymosely, simpodially or in basipetalous succession; $45-121 \times 30-40 \mu \mathrm{m}$. Zoospore pyriform on emergence; discharge and behavior of primary zoospores saprolegnoid; primary zoospore cists $8-10 \mu \mathrm{m}$ diam. Gemmae abundant; globose, subglobose, pyriform, cilindrical; terminal or intercalary; single or catenulate. Oogonia generally terminal, occasionally lateral or intercalary; spherical, obpyriform, occasionally angular or irregular; 18-30 $\mu \mathrm{m}$ diam. Oogonial wall unpitted, smooth, occasionally with 1-2 broad, blunt, inconspicuous protrusions. Oogonial stalk short, straight or irregular; unbranched. Oospores subeccentric; spherical or oval; 1(-3) per oogonium; 14-26 $\mu \mathrm{m}$ diam.; germitation not observed. Antheridial branches usually present, monoclinous on terminal oogonia, androgynous on lateral ones or infrequentelly monoclinous, rarely diclinous; short, slender; unbranched. Antheridial cells short, clavate, curved or bent, occasionally to frequently hypogynous or hemihypogynous; apically or laterally appressed.

P. cymosa can be easily distinguished from $P$. humphreyana by the smaller oogonia and sometimes by having few projections (Figure 1d) and the presence of basal antheridia (Figure 1c) (Coker, 1923). P. cymosa is less ornate and differs from $P$. irregularis by generally irregular and predominantly ornate oogonia, and from $P$. papilliformis by the always conspicuously ornate oogonia. The description of the isolate of P. cymosa obtained in this study agrees with the original description of the taxon and displays morphological characteristics reported by Coker (1923) (Figure 1a-f). Spencer et al. (2002) consider Pythiopsis monotypic consisting of only one subeccentric species, P. cymosa. Most of P. cymosa oospores are spherical and 

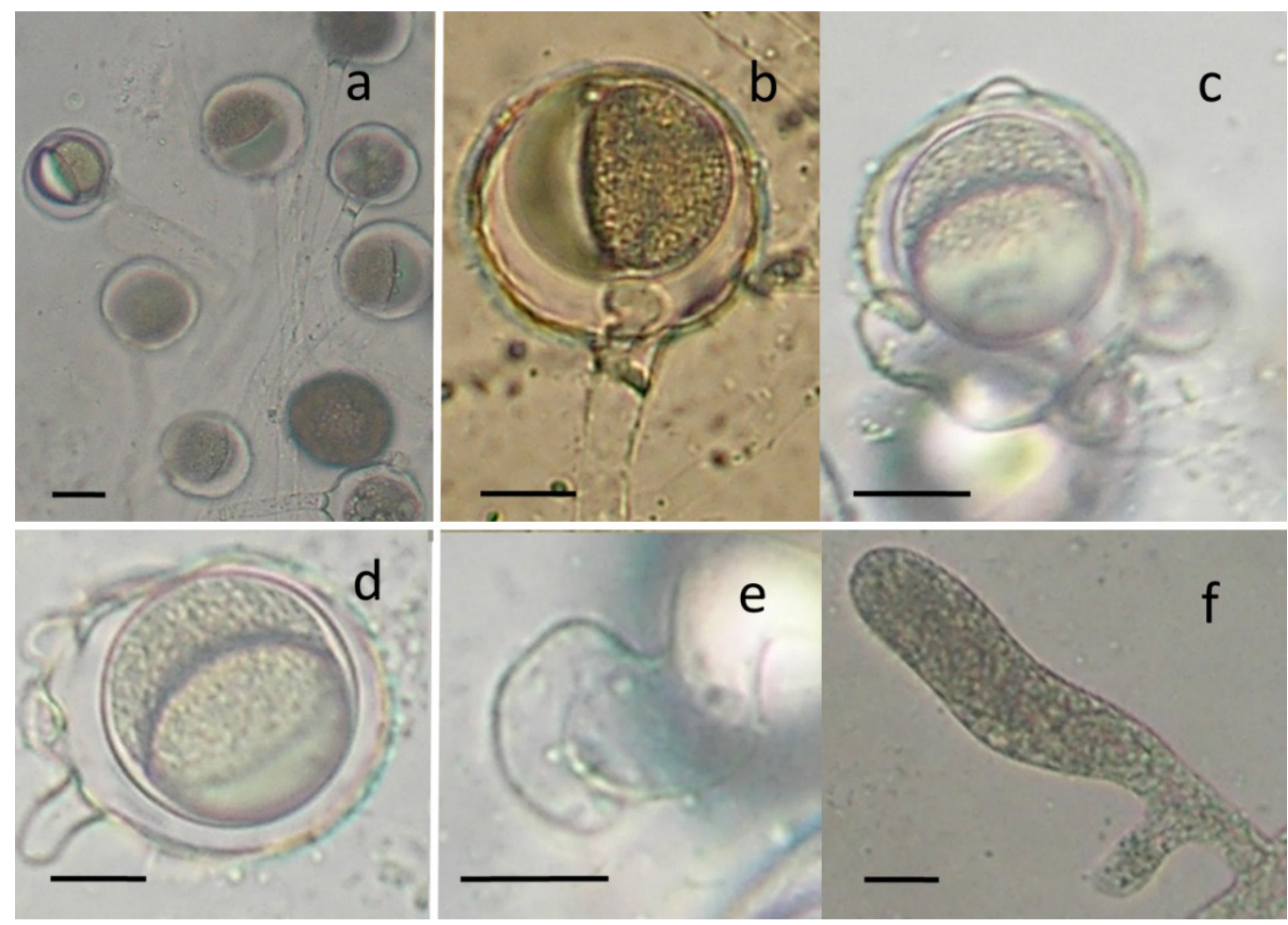

Figure 1. Pythiopsis cymosa de Bary. (a) Aspect general of the oogonia and hyphae; (b) Oogonium with subeccentric oospore; (c) Oogonium with subeccentric oospore. Antheridium hemihypogynous with antheridial cell short and lobed; (d) Oogonium with subeccentric oospore. Oogonial wall with blunt protrusion; (e) Antheridial cell short, curved and apically appressed; (f) Gemmae irregular. Scale Bars $=15 \mu \mathrm{m}$.

the wall is smooth, and each oogonium almost always contains only one subeccentric oospore (Figure 1a-d). The anteridial branches are commonly formed directly below the oogonia, and are strictly androgynous or are hypogenous. Johnson et al. (2002) adopted the term hemyhypogynous by modifying the term semyhypogynous used by Nolan and Lewis (1974) for this hypogynous configuration of the antheridia of Pythiopsis. In this case, the hemyhypogynal cell is usually lobed. This type of antheridium was observed in the isolates obtained in our studies (Figure 1c). Although Pickering and Willoughby (1977) and Willoughby (1978) reported the discovery of an unidentified species of Pythiopsis obtained in fish, there was no information on their pathogenicity. In this study, the isolate was obtained from fish injuries with a symptom of disease, but it was not possible to perform pathogenicity testing. This is the first record of the P. cymosa parasitizing freshwater fish also recording Brazil as new locality for geographic distribution.

\section{Acknowledgements}

The authors thank Universidade Federal do Piauí for the Scientific Initiation scholarship (PIBIC/UFPI-IC 2006/2007) to second author.

\section{References}

COKER, W.C., 1923. The Saprolegniaceae with notes on the water molds. Chapel Hill: University North Carolina Press. 201 p.

JOHNSON, T.W., SEYMOUR, R.L. and PADGETT, D.E., 2002 [viewed 3 August 2015]. Biology and systematic of the Saprolegniaceae [online]. Wilmington: UNCW. Available from: http://www.uncw.edu/people/padgett/book

JOHNSON, T.W., SEYMOUR, R.L. and PADGETT, D.E., 2005. Systematic of the Saprolegniaceae: new taxa. Mycotaxon, vol. 92, no. 1, pp. 1-10.

MAIA, L.C. and CARVALHO, A.A., 2015 [viewed 3 August 2015]. Fungos. In: Jardim Botânico do Rio de Janeiro - JBRJ. Lista de Espécies da Flora do Brasil [online]. Rio de Janeiro: JBRJ. Available from: http://www.floradobrasil.jbrj.gov.br/jabot/ floradobrasil/FB102109

MILANEZ, A.I., PIRES-ZOTTARELLI, C.L.A. and GOMES, A.L., 2007. Brazilian zoosporic fungi. 1. ed. São Paulo: CNPq. 210 p.

NOLAN, R.A. and LEWIS, D.J., 1974. Studies of Pythiopsis cymosa from Newfoundland. Transactions of the British Mycological Society, vol. 62, no. 1, pp. 163-179. http://dx.doi.org/10.1016/ S0007-1536(74)80017-3.

PICKERING, A.D. and WILLOUGHBY, L.G., 1977. Epidermal lesions and fungal infection on the perch, Perca fluviatilis L., in Windermere. Journal of Fish Biology, vol. 11, no. 4, pp. 349-354. http://dx.doi.org/10.1111/j.1095-8649.1977.tb04128.x. 
SPENCER, M.A., VICK, M.C. and DICK, M.W., 2002. Revision of Aplanopsis, Pythiopsis, and 'subcentric' Achlya species (Saprolegniacea) using 18S rDNA and morphological data. Mycological Research, vol. 106, no. 5, pp. 549-560. http://dx.doi. org/10.1017/S0953756202005889.

STECIOW, M.M., MILANEZ, A.I., PIRES-ZOTTARELLI, C.L.A., MARANO, A.V., LECTHER, P.M. and VÉLEZ,
C.G., 2012. Zoosporic true fungi, heterotrophic straminipiles and plasmodiophorids status of knowledge in South America. Darwiniana, vol. 5, no. 1, pp. 25-32.

WILLOUGHBY, L.G., 1978. Saprolegnia of salmonid fish in Windermere: a critical analysis. Journal of Fish Diseases, vol. 1, no. 1, pp. 51-67. http://dx.doi.org/10.1111/j.1365-2761.1978. tb00005.x. 